Acta regionalia et environmentalica 1

Nitra, Slovaca Universitas Agriculturae Nitriae, 2013, p. 1-6

\title{
NATURAL ENVIRONMENT OF SMALL TOWNS AS AN INDICATOR OF THE DEVELOPMENTAL POTENTIAL OF A WIDER REGION - AS EXEMPLIFIED BY THE SOUTH MORAVIAN COUNTRYSIDE
}

\author{
Hana VAVROUCHOVÁ, ${ }^{1}$ Mária PÁKOZDIOVÁ, ${ }^{1}$ Ilona SVOBODOVÁ ${ }^{2}$ \\ Mendel University in Brno, Faculty of Agriculture, Brno, Czech Republic ${ }^{1}$ \\ Masaryk University in Brno, Czech Republic²
}

\begin{abstract}
Our study is focused on the natural environment significance and potential for the development of a wider region. A special emphasis is put on the geographical category of small towns, which play an important role in stabilizing the population of the Czech Republic. In this context, a key factor of planning in the rural region is the demarcation of a catchment region and the determination of its potential. Natural environment (primary landscape structure) is a basic determinant of area development at all the levels. This paper aims at the natural environment analyses of the small towns in the South Moravian Region, with emphasis on the development opportunities and limitations. In this study, small towns are considered to be all the residential units holding a town status, with the exception of district towns and the city of Brno. The study is a part of the research project supported in 2011 by the Internal Grant Agency of Mendel University in Brno titled "Small towns - Motors of the South Moravian countryside development".
\end{abstract}

Keywords: small towns, natural environment, development potential, landscape planning

Developing a land use plan or another strategic plan, we often speak of applying the landscape typology at a simultaneous adjustment of the basic optimum landscape management for each of the landscape types. We have to realize that basic steps of procedures applied in similar landscape types are repeatable, which makes the process simplified and unified. However, the effective methodological procedure, which has been to a limited extent newly applied to the area development planning in the Czech Republic as well (duly for example in the Principles for Area Development issued for a region's territory within the framework of Target Landscape Characteristics) should be further complemented with the specified developmental potential of the area in a wider context. It is exactly the identification and analysis of a small catchment town (or small towns) that may be of essential importance for the specification of driving mechanisms of development and the proposal for a further area management.

For a long time, small towns were not considered to be a special category and their role in the formation of rural space remained underestimated. However, the latest research confirms their significance for the development and integration of rural areas. Geography of small towns has been studied for example by Vaishar et al. (2001), Slavík (2002), Sokołowski (1999) or Cigale (2006). Courtney (2003; 2007) pointed out the potentiality of small towns in the regional context.

The role of small towns is of key importance, especially by ensuring functionality and sound living standard in (micro) regions and for the saturation of basic socio-economic requirements of their inhabitants. This does not relate to services in the narrow sense of the word but particularly job opportunities, possibilities of education and social contacts. In this context, we can often speak about the dependence of the prosperity of rural municipalities on the prosperity of their catchment centres (usually small towns).

Natural environment (primary landscape structure), its current and historic use (secondary landscape structure) and conservation constitute a basic determinant for the future area development. The analysis of small towns in the context of above-mentioned characteristics is very useful for the initial stages of a strategic landscape planning. As pointed out by Schaeffer (2000), a land use plan or any other regional plan should be based on a comparative advantage, which may be the healthy natural environment.

\section{Material and methods}

In this work, small towns are considered to be all the residential units with a town status, with the exception of district and regional towns. In the South Moravian Region, there are 43 municipalities falling into this category. A large number of them are located in the southern part of the Region (17 municipalities with more than 5,000 inhabitants, the other ones falling in smaller-sized categories).

The basic method used in the application part is analysis and comparative analysis (at the level of districts). The part of work, in which the basic typology of small towns according to the current state and developmental potential is defined, uses the method of synthesis and analogy.

The environment analysis is differentiated into the following scopes:

- primary landscape structure,

- nature conservation,

- land use.

Small towns of the South Moravian Region represent an extensive set of heterogeneous areas. This is why we 
could obtain the groundwork data only from the complex public databases (namely year books issued by the Czech Statistical Office, Central List of Nature Conservation) and data published on the public authorities' portal. Natural environment areas of small towns in the South Moravian countryside explored and statistically evaluated by means of map servers and other sources were as follows:

- geology, landscape typology according to the relief',

- soil types and wind and water erosion threats ${ }^{2}$,

- climatic zone ${ }^{3}$,

- catchment areas, flood threat categories, inundation areas $^{4}$,

- potential natural vegetation ${ }^{5}$,

- Corine Land Cover ${ }^{6}$.

Stemming out from the above-mentioned themes, the analytical part creates the basis of starting points for the differentiation of small towns according to the framework development potential, which was established on the basis of synthesis as follows:

- organic farming (selection of the areas with the most fertile soils, warm climatic areas, without or with only mild threat of water or wind erosion and with a high share of arable land per capita/above 3,000 $\mathrm{m}^{2}$ per inhabitant);

- low-impact tourism (determined by natural environment and/or by a combination with cultural values/selection of areas with a representation of relatively stable landscape parts over $50 \%$, a high proportion of forest land per inhabitant, absence of large industrial and business centres);

- mixed potential (selection of areas with fertile soils in the mild-warm zone, with soils slightly endangered by water or wind erosion or susceptible soils, with a share of relatively stable landscape parts ranging from 35 to 50\%);

1 Geological data of the surveyed territory were established from the Geological map of the map server of the INSPIRE national geo-portal available on the websites of CENIA (Czech Environment Information Agency).

2 Information about the representation of individual soil types and sub-types occurring on the surveyed 43 cadastral areas of small towns in the South Moravia countryside was gained from the layer Types according to the Taxonomic Classification System of Soils in the Czech Republic - map server of the INSPIRE national geo-portal available on the websites of CENIA (Czech Environment Information Agency).

3 The data were acquired from the map server of AOPK (Agency for Nature Conservation and Landscape Protection of the Czech Republic) - classification of climatic zones according to Quitt (1971).

4 The data were acquired from the Flood Plan Data Editor of Hydrosoft Veleslavín and from the Study of flood control measures in the territory of South Moravia Region (Pöyry Environment a.s.)

5 Potential occurrence of units of the potential natural vegetation was ascertained from the map server of AOPK (Agency for Nature Conservation and Landscape Protection of the Czech Republic) - classification of vegetation units according to Neuhäuslová (1997).

6 Data about the current land cover of the surveyed area were ascertained from the Corine 2006 layer of the map server of the INSPIRE national geo-portal available on the websites of CENIA (Czech Environment Information Agency). The latest results of land cover mapping in the Corine programme originate from 2006.

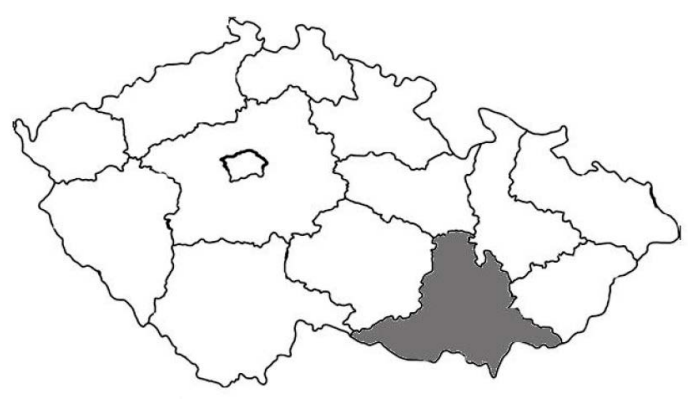

Figure 1 South Moravian Region's location in the Czech Republic

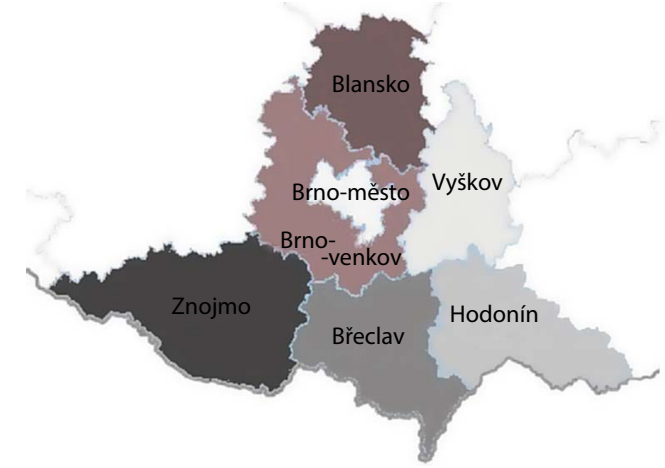

Figure 2 The region zoning

- nature conservation (selection of an area valuable in respect of nature conservation and landscape protection, with over $30 \%$ of protected areas (including nature parks) on the cadastral area, areas with a preserved natural environment);

- extraction of minerals (municipalities with the exploited deposits of minerals and assumed further mining, without limitations of nature conservation and landscape protection);

- other potentials (important from another than natural environment point of view - e.g. housing potential, urbanization etc. and/or high risk of floods).

\section{Results and discussion}

\section{Geological basement}

Geological basement of most small towns' cadastral areas in the South Moravian Region countryside is formed by Quaternary loam, loess, sands and gravels, as well as by Tertiary sands and clays.

\section{Soils}

The most frequently occurring soil type is Chernozem, which is represented in a majority of small towns (in 34 monitored small towns) ${ }^{7}$, together with Fluvisol (in 32 small towns). Another relatively frequently occurring soil type is Luvisol (ca. a half of the small towns), Cambisol (ca. a half of the

7 In one cadastral area, there are various soil types and subtypes. This is why a sum of cadastres in which the individual soil types are represented does not give the resulting studied number of cadastres, i.e. the set of 43 small towns. 
small towns) and Phaeozem (20 small towns). Haplic Leptosols, Stagnosols, Arenosols and Rendzinas have a lower representation.

\section{Wind and water erosion threat}

According to the classification specified on the pages of the Sowac GIS VÚMOP (Research Institute of Soil and Water Conservation) project, the layer of Arable land in cadastres threatened by wind erosion and the layer of potential threat of water erosion in cadastres in the area of interest include soils slightly threatened by (wind and water) erosion, threatened, severely threatened and most threatened, soils susceptible to wind or water erosion, as well as soils without wind or water erosion threat. The majority of soils in the area are soils slightly threatened by the wind erosion (12 cadastral areas) and soils slightly threatened and threatened by the water erosion.

\section{Catchment areas and flood risk}

A greater part of the analyzed area falls into the Dyje River catchment, the remaining part belongs to the Morava River catchment (Velké Opatovice, Bzenec, Strážnice, Veselí nad Moravou, Ždánice, Ivanovice na Hané).

\section{Climatic zones (Quitt, 1971)}

A greater part of the analyzed area falls into the warm climatic zone (T). Nearly a half of the small towns in the South Moravian Region belong to the warm zone T 4 (dominating are small towns of the Břeclav district and Hodonín district) and nearly a quarter of small towns belong to the warm zone T 2 (namely small towns in the Vyškov district). The remaining portion of the territory belongs to the mild warm climatic zone (MT), namely the district of Blansko.

\section{Nature conservation}

There are altogether 50 small-scale strictly protected areas on the concerned cadastres ( $2 / 3$ with a status of nature monument). The distribution of these small-scale nature values in the individual districts of the Region is relatively equable. However, none of them occur in a nearly half of the studied small town areas. Large-scale protection is applied on three localities in the form of a protected landscape

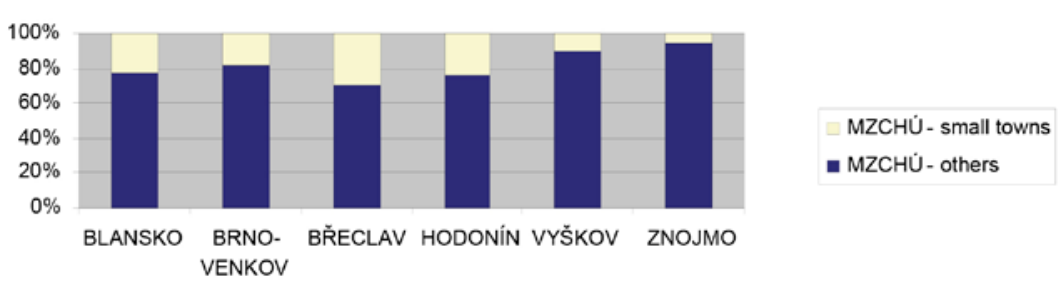

Figure 3 Proportion of the cadastral areas of small towns in the total number of small-scale strictly protected areas (MZCHÚ) in the districts of South Moravian Region

Source: The Central List of Nature Conservation and Landscape Protection, AOPK; own modification

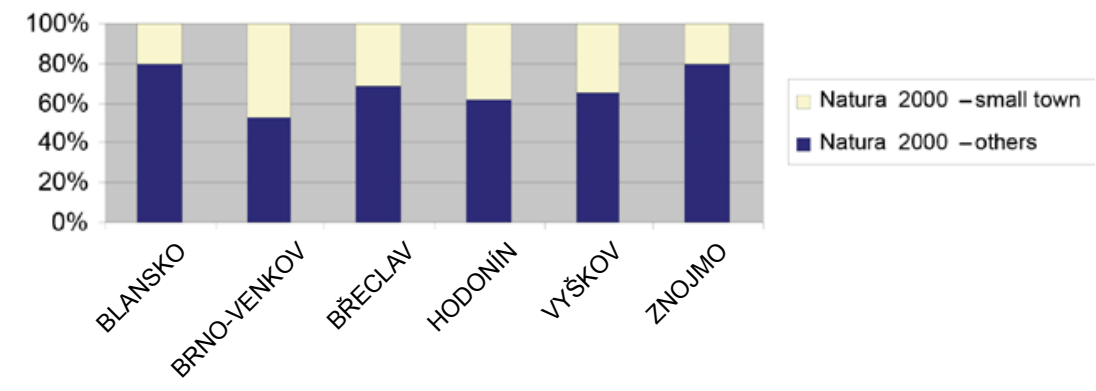

Figure 4 Proportion of the cadastral areas of small towns in the total number of NATURA 2000 areas in the districts of South Moravian Region Source: The Central List of Nature Conservation and Landscape Protection, AOPK; own modification

area (Adamov - whole territory falls into the Moravian Karst Protected Landscape Area, Mikulov - $81 \%$ of the territory belongs to the Pálava PLA and Strážnice $-47 \%$ of the territory belongs to the White Carpathians PLA).

NATURA 2000 is represented in the small towns of the South Moravian Region by 48 sites of Community interest and by 4 avian areas. Within this form of conservation, the distribution of these areas in the individual districts is relatively equable, too. The NATURA 2000 area does not reach into a third of the monitored territories.

Figure 3 and 4 show the relative representation of the elements of small-scale nature conservation and NATURA 2000 system in small towns, with respect to the total number of these elements in the districts of the South Moravian Region. The lowest relative and absolute occurrence of small-scale strictly protected areas (MZCHÚ) is in the districts of Vyškov and Znojmo; the highest occurrence of them is in the districts of Břeclav and Hodonín. In the case of the NATURA 2000 , the largest areas can be found in the districts of Brno-Province and
Hodonín, the lowest in the districts of Blansko (balanced however by largescale nature conservation) and Znojmo. The highest rate of the relative and absolute abundance of valuable parts of nature and landscape (including the large-scale nature conservation) are in the districts of Břeclav and Hodonin.

There are 5 levels of nature conservation significant for a further area development that can be distinguished according to the relative and absolute representation of the protected areas and the degree of their conservation (very important, important, medium important, little important, unimportant). Nature conservation plays a very important or important role for nearly a fifth of municipalities, contributing significantly to the formation or limitation of a further area development. In two thirds of the small towns, nature conservation is not considered to be a priority.

General nature conservation (pursuant to Act No 114/92 Coll.) is represented by nature parks, which can be found on the territories of seven monitored small towns. Another important phenomenon in the 
Table 1 Maximum and minimum shares of some cultures per capita and the median of the set

\begin{tabular}{|c|c|c|c|c|}
\hline Indicator & Arable land in $\mathrm{m}^{2}$ per capita & Forest land in $\mathrm{m}^{2}$ per capita & Built-up area in $\mathrm{m}^{2}$ per capita & Gardens in $\mathbf{m}^{2}$ per capita \\
\hline Maximum & 8,302.9 (Klobouky u Brna) & 8,382.3 (Lanžhot) & 238.3 (Bzenec) & 382.6 (D. Kounice) \\
\hline Minimum & 460.7 (Židlochovice) & 2.6 (V. Bílovice) & 49.0 (Adamov) & 23.4 (Adamov) \\
\hline Median & $2,400.1$ & 523.3 & 132.8 & 136.9 \\
\hline
\end{tabular}

Source: Data of the Czech Statistical Office (ČSÚ) from 2010, own calculations

protection of cultural landscape is the Man and Biosphere programme (UNESCO). Cadastres included in the project are those of Strážnice, Mikulov and Valtice (Biosphere Reserve of the White Carpathians and Lower Morava).

\section{Land use}

Small towns in the South Moravian Region have (except for one specific case where the area development plan has been cancelled) area development plans, which are either approved or in progress. In most of the cases, the area development plan in question has been prepared and approved according to the old construction law ${ }^{8}$. Only a quarter of small towns have the area development plans prepared according to the new law at a different stage of progress.

The proportion of built-up area in the South Moravian Region small towns ranges from $0.9 \%$ (Lanžhot) to $8.5 \%$ (Modrice). However, the median of the set is in the lower third of the interval and reaches $2.8 \%$ of the built-up area. The highest proportion of built-up areas is in the small towns of the Brno-Province district, the lowest proportion of built-up areas is in the district of Znojmo.

In the period from 2001 to 2010, the share of built-up areas was increasing significantly only in a tenth of the studied small towns. An average distance of these localities from the regional town of Brno is $20 \mathrm{~km}$. Other small towns in the hinterland of the South Moravian metropolis will probably take over the trend in the future (e.g. Rajhrad, Rosice) although the hitherto growth rate cannot be anticipated. In the studied period, the analyzed small towns showed also a decrease in the size of built-up land (significantly in Mikulov, Dubňany and Veselí nad Moravou). In the district of Znojmo, the built-up area size is stabilized. Similar situation can be observed in the Vyškov district, while the Hodonín district shows rather decreasing built-up area.

The share of arable land was growing the most significantly in the period from 2001-2010 in Rájec Jestřebí and in Dolní Kounice. Other small towns exhibited a decrease, which was most significant in Valtice, Mikulov, Pohořelice, Hustopeče and Velké Bílovice. In general, the most significant decreases in the acreage of arable land were recorded in the small towns of the Břeclav district. Forest land area was growing in a majority of cadastres (significantly in Pohořelice, Rosice, Valtice and Dubňany - by ca. 20 ha). A fairly significant decrease was recorded in Hustopeče. The

8 The Act No 50/1976 Coll. on area planning and building regulations was amended by the Building Act No 183/2006 Coll. of 1 January 2007. Area development plans approved under the old act have to be updated according to the current legislation until 31 December 2020 otherwise they will become invalid. area of permanent grasslands was significantly growing in Podivín (ca. 50 ha) and decreasing in Lanžhot (ca. 35 ha).

The proportion of relatively stable landscape constituents (forest stands, permanent grasslands, water bodies, gardens, orchards, vineyards) in the Region ranges from 5.5\% (Ivanovice na Hané) to $71.5 \%$ (Adamov and Kunštát). The shares are distinctly lowest in the districts of Vyškov and Znojmo, the highest in the Hodonín and Blansko districts. The median of the set is in the middle of the interval with $35.1 \%$ of relatively stable areas. Only a quarter of the small towns in the South Moravian Region show an above-half proportion of relatively stable areas in their territory, which may to a certain extent indicate the quality of life and the landscape's potential for the development of tourism.

A significant decrease in the proportion of relatively stable landscape constituents can be observed only in Dolní Kounice. By contrast, a significant increase was recorded in all small towns in the Breclav district. Tab. 1 presents maximum, minimum and median values of the set of small towns according to selected criteria.

\section{Landscape typology}

On the one hand, small towns of the South Moravian Region fall in the agricultural or agricultural-forest landscape types. Exceptional are small towns in the hinterland of the regional town of Brno (Modřice, Rajhrad, Šlapanice), for which urbanized areas in a broader territorial context represent a determining factor. On the other hand, there are also small towns with the dominating forest type of the landscape in the South Moravian Region (Adamov, Kunštát, Moravský Krumlov). Methodology chosen for the classification of landscape type is that by Löw (2006), which is also applied in a majority of Principles for the area development of regions in the Czech Republic.

The natural environment of small towns in the South Moravian Region can be seen as a comparative advantage based on the strategies that can be designed of a further development. Assuming that the small towns currently play an important role in the development of a broader region, we can see that it is exactly the natural environment, which is one of primary prerequisites for the formation of this trend. The following brief SWOT analysis shows the potential of the small towns environment within the South Moravian Region as related to its further use.

As mentioned above, the small towns of the South Moravian Region were divided into four basic categories according to their developmental potential and one complementary category (ad Fig. 5).

The areas of development were chosen with regard to the preservation and enhancement of the natural environment qualities. Nevertheless, determining for 


\begin{tabular}{|l|l|}
\hline \multicolumn{1}{|c|}{ S } & \multicolumn{1}{c|}{ W } \\
\hline $\begin{array}{l}\text { - relatively preserved natural environment, } \\
\text { - heterogeneous landscape with rare communities, } \\
\text { - combination of nature values and cultural elements }\end{array}$ & $\begin{array}{l}\text { - degradation of natural environment in post-industrial areas, } \\
\text { - degradation of natural environment due to intensive agriculture } \\
\text { (partially also with its subsequent down-scaling) }\end{array}$ \\
\hline \multicolumn{1}{|c|}{$\mathbf{T}$} \\
\hline $\begin{array}{l}\text { - development of recreation in areas with a high share of } \\
\text { relatively stable components of natural environment, } \\
\text { - increasing share of arable land farmed by environment- } \\
\text { friendly methods, } \\
\text { - increasing landscape attractiveness for existing and new } \\
\text { residents }\end{array}$ & $\begin{array}{l}\text { - proceeding suburbanization with economic, social and ecological } \\
\text { consequences, } \\
\text { - appropriation of land for energy purposes, }\end{array}$ \\
\hline
\end{tabular}

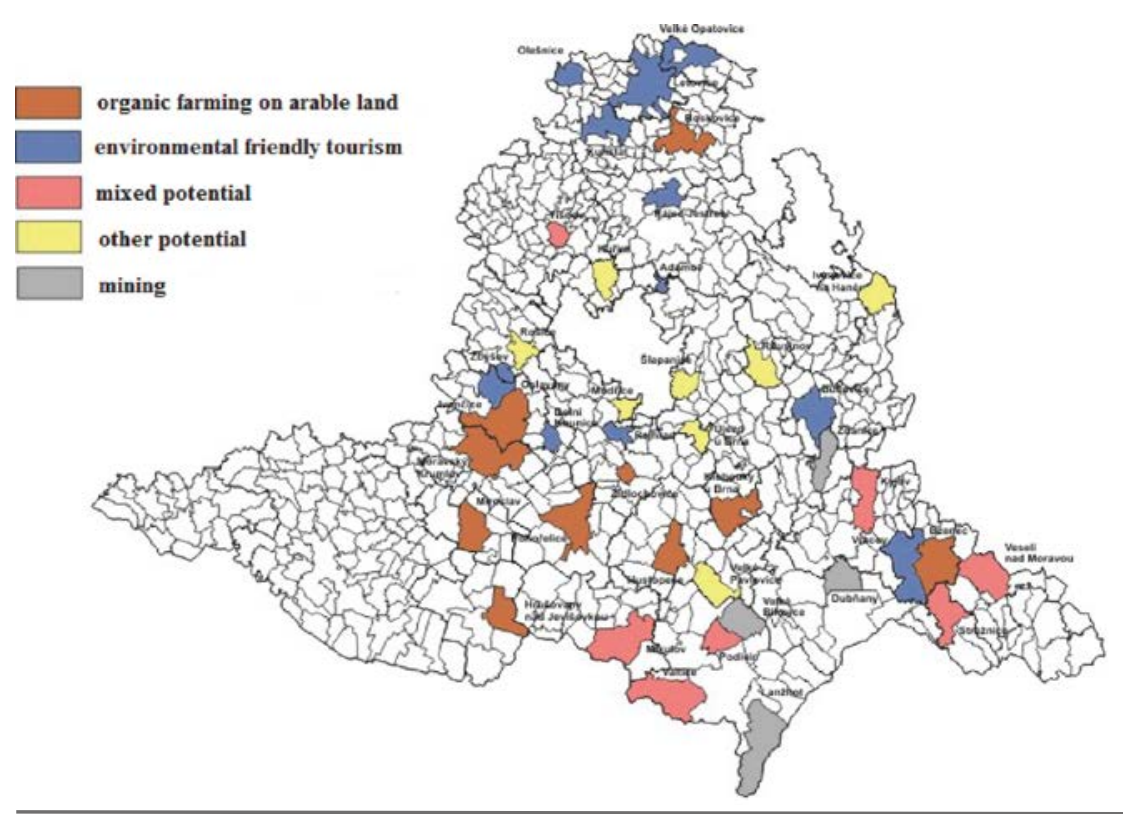

Figure 5 Division of the small towns according to a set of determined development potential of natural environments - graphical overview Source: Author

a further development of small towns in the South Moravian Region may be the fact that nature conservation plays a very important or important role only in a fifth of them (thus significantly contributing to the formation or limitation of a further area development) and that it is not considered a priority in two thirds of the small towns. In this context, many small towns are threatened by suburbanization of both commercial and residential character. Moreover, symptomatic for the South Moravian Region in the past period was the development of solar power plants built on agricultural land resources. With respect to the climatic conditions of the Region, a certain limited potential for a further development can be still seen (especially in the districts of Břeclav and Znojmo); important should however be the
9 unused areas with remainders of the previous land use planning and methods of this research are applicable as input theses for this form of area management. Developing a land use or another strategic plan, it is useful to set the territory into a broader context because the identification and analysis of a small catchment town (or small towns) may be essential for the specification of development motors, as well as for the proposal of a further area management.

State and trends of area development:

- due to the suburbanization processes, the highest shares of built-up land are recorded in the district of Brno-Province. As expected, the smallest urbanized area is in the borderland of the Znojmo district. Expected trends are as follows: The new Building Act puts considerable limitations on new sites available for building and this is why no important increase in the size of built-up areas is expected. Nevertheless, the Principles for Area Development in the South Moravian Region count with a minimum land appropriation at ca. 5,900 ha (as a rule for linear constructions reaching into the cadastral areas of small towns).

The structure of the agricultural land resources in the South Moravian Region is very specific, particularly in respect of climatic characteristics (as well as in terms of land use in general). The area of arable land in the small towns has been decreasing in line with general trends in the sector of agriculture. By contrast, the area of relatively small-sized permanent grasslands on these cadastres has been slightly increasing. However, compared to the national scale, the proportions can be considered below average. The increasing acreage can be expected also in the future, most 
probably to the detriment of arable land (with the greatest potential being seen in the Vyškov district).

Forest cover percentage is highly diversified; the lowest and highest forest percentage is in the Židlochovice and Blansko districts, respectively. The Region shows a longterm increasing trend in the afforestation of sites whose agricultural use is difficult and this trend will concern also the cadastral areas of small towns in the future.

From the viewpoint of the small towns and their natural potential, other land use categories are unimportant.

\section{References}

AOPK (Agentura ochrany prírody a krajiny ČR). Www.mapy.nature.cz [online]. 2008 [cit. 2011-08-06]. Přírodní poměry - Klimatická oblast. et Vegetace - Mapa potenciální přirozené vegetace. Dostupné z: <http://mapy.nature.cz/mapinspire/MapWin. aspx?M_WizID=8\&M_Site=aopk\&M_Lang=cs >

CENIA (Česká informační agentura životního prostředí). Www. geoportal.gov.cz [online]. 2009 [cit. 2011-08-22]. Geologická mapa. et Typologie české krajiny podle reliéfu. et Klasifikace půdních typů podle TKSP (Taxonomický klasifikační systém půd ČR). Dostupné $z<$ http://geoportal.gov.cz/web/guest/map >.

CENIA (Česká informační agentura životního prostředí). Www. cenia.cz [online]. 2007, 2011 [cit. 2011-08-26]. Botanické mapy. Dostupné z <http://www.cenia.cz/_C12571B20041E945. nsf/\$pid/CENMSFME9PAZ>.

CIGALE, D. - LAMPIČ, B. - OGRIN, M. - PLUT, D. - REBERNIK, D. - ŠPES, M. - VINTAR MALLY, K. - CETKOVSKÝ, S. - KALLABOVÁ, E. -MIKULÍK, O. - VAISHAR, A. -ZAPLETALOVÁ, J. 2006. Sustainable development of small towns a Slovenian-Moravian comparative methodological approach. In: Moravian Geographical Reports, vol. 14, 2006, no. 1, p. 17-28.

COURTNEY, P. - ERRINGTON, A. 2003. Small towns as sub-poles in Euroepan Rural Development: Policy, theory and methodology (paper on Agricultural Economics Society Annual Conference, University of Plymouth). University of Gloucestershire Cheltenham. 2003.

COURTNEY, P. - MAYFIELD, L. - TRANTER, R. - JONES, P. - ERRINGTON, A. 2007. Small towns as, sub-poles' in English rural development: investigating rural-urban linkages using sub-regional social accounting matrice. In: Geoforum, vol. 38, 2007, no. 6, p. 1219-1232. 43 ref. Elsevier Oxford. ISSN 0016-7185.
HYDROSOFT VELESLAVÍN. Www.wmap.cz [online]. 2004-2010 [cit. 2011-08-26]. Editor dat povodňového plánu - Záplavová území. Dostupné z: <http://www.wmap.cz/pk_zapluz/>.

LÖW, J. - CULEK, M. - HARTL, P. - NOVÁK, J. 2006. Krajinné typy České republiky. In: Sborník 23. výroční konference Fyzickogeografické sekce ČGS. 1. vyd. Brno : Geografický ústav MU. 2006. QUITT, E. 1971. Klimatické oblasti Československa. Brno : Československá akademie věd - geografický ústav, 1971, 73 s.

SCHAEFFER, P. 2000. Small town and rural economic development: a case studies approach. Publisher : Greenwood Press. ISBN-10: $0275965767.312 \mathrm{p}$.

SLAVÍK, V. 2002. Small Towns of the Slovak Republic within the transformation stage. In: Matlovič, R., Žigrai, F.: Wandel der regionalen Strukturen in der Slowakei und im österreichischslowakischen Grenzgebiet. Prešovská univerzita, Prešov, 2002, p. $146-154$.

SOKOŁOWSKI, D. 1999. Funkcje centralne w zbiorze małych miast i większych osiedli wiejskich w Polsce. In: Przegląd geograficzny, vol. 71, 1999, no. 3, p. 295-316.

ÚVT, s. r. o. a BENETA.cz, s. r. o. Http://klasifikace.pedologie.czu. Cz/ [online]. 2004 [cit. 2011-08-27]. Taxonomický klasifikační systém půd ČR. Dostupné z: <http://klasifikace.pedologie.czu. Cz/index.php?action=showHomePage $>$.

VAISHAR, A. - HLAVINKOVÁ, P. - HOFÍRKOVÁ, S. - HRÁDEK, M. - KALLABOVÁ, E. - KIRCHNER, K. - KLIIMOVÁ, A. - LACINA, J. ONDRÁČEK, S. - QUITT, E. - ŠKRABALOVÁ, J. - TRÁVNÍČEK, B. - ZAPLETALOVÁ, J. 2001. Geography of small Moravan towns: case study Bučovice. In: Moravian Geographical Reports, vol. 9, 2001, no. 1, p. 43-62.

VÚMOP (Výzkumný ústav meliorací a ochrany půd ČR). Http:// ms.sowac-gis.cz/mapserv/php/maps.php [online]. 2008, 14. 2. 2011 [cit. 2011-08-11]. SOWAC GIS vodní a větrná eroze půd ČR. Vrstva: Ohroženost orné půdy větrnou erozí na katastry. et Vrstva: Potenciální ohroženost katastrů vodní erozí. Dostupné z: <http://ms.sowac-gis.cz/mapserv/dhtml_eroze/index. php?project=dhtml_eroze\& $>$.

\section{Contact address:}

Mgr. Ing. Hana Vavrouchová, Ph.D., Department of Applied and Landscape Ecology, Faculty of Agriculture, Mendel university in Brno, Zemědělská 1, 61300 Brno, Czech republic, e-mail: hana.vavrouchova@mendelu.cz. 